\title{
The Effect of Organization Climate on Performance with Job Satisfaction as an Intervening Variable
}

\author{
Paisal $^{1, *}$, Afrizawati $^{2}$, Divianto $^{3}$, Yahya $^{4}$ \\ ${ }^{1-4}$ Bussiness of Management Department of Bussiness Administration State Polytechnic of Sriwijaya, Indonesia \\ *Corresponding author Email: paisal.conk@gmail.com
}

\begin{abstract}
This study aims to determine how the influence of organization climate on performance with job satisfaction as an intervening variable. This study uses primary data taken through a questionnaire. The research sample consisted of 126 respondents who were permanent education staff in Sriwijaya State Polytechnic. From the test results using path analysis techniques using the SPSS program. The results of this study indicate that organizational climate has a significant effect on job satisfaction with a coefficient value of 0.062 , significant $\mathrm{t}=0,000$, and job satisfaction has a significant effect on performance with a coefficient of 0.405 , significant $\mathrm{t}$ $=0,000$. Indirectly, the organizational climate significantly influences performance through job satisfaction. Whereas directly organization climate does not have a significant effect on performance with a coefficient value of 0.084 , significant $t=0.306$. Sriwijaya State Polytechnic needs to increase job satisfaction, this includes satisfaction with salary or wages, the job itself, co-workers leaders or superiors, promotion position, and work environment/organization. This is because employee job satisfaction has a significant and positive influence on the performance of education staff. The Head of Sriwijaya State Polytechnic needs to provide the broadest opportunities or freedom to the staff of educational staff to increase motivation, ability, ideas and develop their potential. With the opportunity or freedom that can create support and positive development for all activities carried out to improve performance.
\end{abstract}

Keywords: organization climate, job satisfaction, performance

\section{INTRODUCTION}

Organization climate has an important role in improving employee performance. Organization climate results in the emergence of environmental patterns that bring up motivation and focus on sensible perceptions and impact on employee performance. Defines of the organization climate as a collection and environmental patterns that determine the emergence of motivation and focus on perceptions that are reasonable or can be assessed, so that it has a direct influence on the performance of organization members.

According to observations by organization climate researchers at Sriwijaya State Polytechnic, it is felt that it is already quite good, it is expected to continue to improve so that job creation and employee performance will be improved. The existing organization climate is felt to be able to be built to provide things that can satisfy employees, and there is no longer any hesitation and fear of employees in arguing or disagreeing with the leadership to improve employee performance.

Llocus of control, discipline, organization commitment and work motivation, while external factors are derived from the work environment such as the perception of organization support, organization climate and leadership quality [1].
The Polytechnic is one of the state tertiary institutions in Palembang that is actively trying to continuously improve job satisfaction and the performance of its employees to provide maximum results for the Polytechnic's own goals. Since its establishment in 1982 until now there have been many changes along with the times and the demands of society in the world of education.

According to observations by organization climate researchers at Sriwijaya State Polytechnic, it is felt that it is already quite good, it is expected to continue to improve so that job creation and employee performance will be improved. The existing organization climate is felt to be able to be built to provide things that can satisfy employees, and there is no longer any hesitation and fear of employees in arguing or disagreeing with the leadership to improve employee performance.

It is necessary to better socialize the goals or vision and mission of the Sriwijaya State Polytechnic so that employees can be understood clearly. Does the organization climate that exists in the Sriwijaya State Polytechnic can provide job satisfaction which will ultimately improve the performance of its employees, this is according to interesting researchers to study and hopefully the results of this study can provide benefits for the development of the Sriwijaya State Polytechnic going forward.

In improving employee performance, supporting factors such as organization climate and job satisfaction are also needed. Organization climate is closely related to the 
process of creating a conducive work environment, to create harmonious relationships and cooperation among employees. According to Kristiana [2], the organization climate has a positive influence on employee performance, this is seen from changes in performance that are influenced by organization structure, rewards, responsibilities, risks, tolerance, and conflict. Ostroff in Affandi [3], assumes that a conducive organization climate is a prerequisite for maximum employee performance improvement.

\section{LITERATURE REVIEW}

\subsection{Organization Climate}

Each organization or company has its way of presenting its business. Therefore, an organization has a different climate from other organizations. Climate can be oppressive, neutral or can also be supportive, depending on the part governing it, therefore every organization always has a unique work climate. Organizations tend to attract and retain people according to their climate so that to some degree the pattern can be lasting. To better understand the organizational climate the following will be explained in terms of organizational iklmi according to several experts, including:

According to Wirawan [4], organizational climate is "the perception of members of the organization (individually and in groups) and those who are constantly in contact with the organization (eg suppliers, consumers, consultants and contractors) about what is or happens in the internal environment of the organization as a whole. routine, which influences the attitude and behavior of the organization and the performance of members of the organization which then determines the performance of the organization ". Luthans in Simamora [5]. states that organization climate is "Internal environment or organization psychology. Organization climate influences HR practices and policies accepted by members of the organization. Please note that each organization will have a different organization climate. The diversity of jobs designed within the organization or the nature of the individuals that exist will illustrate these differences ".

\subsection{Factors that Influence Organization Climate}

Anarogo and Widiyanti [6], suggested that: "the factors that influence the organizational climate are work ethic, work discipline, satisfaction, communication and stress and conflict in organizations." This was made clear by Nia $\mathrm{K}$ [7], that to measure climate organization can be seen through the difference between the existing climate and the expected climate. There are 7 dimensions carried out in an effort to measure the organizational climate, which are as follows:
1. Conformity, if many organizations have rules that must be obeyed by workers even though these rules have no relevance or relation to the implementation of work.

2. Responsibility, if every decision taken in an organization is carried out by the leadership, the organization is said to have a low organization climate, because basically subordinates are not given the opportunity to participate in the organization.

3 . In return, every activity carried out and getting good results or achievements does not get any award from the company otherwise if done wrong then the employees are given severe penalties, such a work climate is called a work climate with low rewards.

4. Group spirit, if in the organization people are suspicious of each other and it is difficult to trust and there is no group feeling then this work climate is called low work morale.

5. Clarity, an organization has unclear work procedures, people feel they do not know for sure which responsibilities and authorities.

6. Standards, stipulations about the quality of the work done by members.

7. Leadership, to create an effective organization there needs to be an organizational climate that includes high employee expectations, a positive attitude, an organized curriculum and employee reward and intensive systems.

According to Sugiyono [8] in this study the organizational climate indicators studied included: autonomy and flexibility, trust and openness, sympathetic and giving support, respecting honesty, clarity of purpose, risky work.

\subsection{Job Satisfaction}

The term job satisfaction can be defined as a positive feeling which is the result of an evaluation of its characteristics. Job satisfaction is an individual thing. Each individual has a different level of satisfaction, as defined by Kreitner\&Kinicki [9], that job satisfaction as effectiveness or emotional response to various aspects of work. This definition implies that job satisfaction is not a single concept, on the contrary a person can be relatively satisfied with an aspect of his work and not satisfied with one or several other aspects. Herzberg also believes that there are four factors that affect one's job satisfaction, namely: Psychological Factors, Social Factors, Physical Factors, and Financial Factors.

Based on the opinion of Hariandja [10], the indicators of job satisfaction can be divided into:

1. Salary or wages, i.e. the amount of payment a person receives as a result of carrying out work, is appropriate to the needs and is felt to be fair.

2. The work itself, that is the content of the work carried out by someone, does it have satisfying or unsatisfactory elements.

3. Co-workers, ie friends to whom someone always interacts in the implementation of work. Someone can feel that his co-workers are very pleasant or unpleasant. 
4. Superiors or leaders, that is someone who always gives orders or instructions in carrying out work. Policies that are run by superiors can be unpleasant or pleasing to someone and this can affect job satisfaction.

5. Promotion or opportunity to advance, that is the possibility that someone can develop through promotion. A person can feel that there is a high possibility of promotion or not, the promotion process is open or not open. This can also be affect the level of job satisfaction of a person / individual.

\subsection{Performance}

Employee Performance is a result of the synergy of a number of factors. These factors are the employee's internal environmental factors, organizational internal environmental factors, and organizational external environmental factors. Panggabean [11], describes employee performance appraisal as a formal process to periodically review and evaluate one's work performance. The assessment process is intended to understand one's work performance. It was also further explained that employee performance appraisal is a process aimed at obtaining information about employee performance. This information can be used as input in carrying out almost all resource management activities manusialainnya other human beings such as promotion, salary increase, development, and termination of employment.

According to Simamora [12], performance (performance) refers to the level of achievement of the tasks that make up an employee's work. Performance reflects how well employees meet the requirements of a job.Achievement of the goals set is one of the benchmarks of individual performance. According to Robbin [13], there are three criteria in evaluating individual performance, namely: (a) individual tasks; (b) individual behavior; and (c) individual characteristics.Performance related to the willingness of a person or group of people to do an activity in a certain time and perfect it in accordance with their responsibilities with the results as expected and can be measured.

Performance Measurement

Interpersonal impact, is the degree to which employees maintain, self-esteem, good name and cooperation between colleagues and subordinates. The employee performance indicators according to Bangun [14] as follows:

a. Quality

Measured from employee perceptions of the quality of work produced and perfection assignments to the skills and abilities of employees.

b. Quantity

Represents the amount of work produced expressed in terms such as the number of units, the number of activity cycles completed.

c. Punctuality

The level of activity is completed at a predetermined time, it can be seen from the point of view of coordinating with the outputs and maximizing the time available for other activities.

\subsection{Empirical Review}

Previous studies have shown that type of organization is related to job satisfaction components. In the study of nonprofit employees, Similar results were also found by Joseph and Deshpande [15], in their study of 226 nurses in a 169-room non-profit hospital in the United States, with 114 respondents who were on average 40 years old and had worked for 9 years. From this research it indicates that the hospital can increase the job satisfaction of its nurses by handling the organizational climate. The same study Koh and Boo, 2001 [16], found that the type of organizational ethical climate is related to job satisfaction and overall performance.

Job satisfaction is one of the most concepts in the management literature, accounting for more than 5000 literature that explains it. The information that will be obtained through this research, will have practical implications for the performance of individuals and organizations in the same way. According to Wilson [17], employees want to get the best quality of life, both for themselves and their families, hence understanding the level of job satisfaction and orientation, is not only expected but also becomes a critical or important aspect of life for individuals and organizations.

\section{RESULTS AND DISCUSSION}

\subsection{The effect of organizational climate on performance}

According statistical inferential analysis has using path analysis or multiple linear regression analysis, the second hypothesis has states organizational climate a significant effect on performance, but is not proven and the hypothesis was rejected.

The direct effect of organizational climate on performance is not significant because the significance value of $t$ is more than 0.05 which is equal to 0.306 . The factor that caused the insignificance of the organization's climate on performance was because the staff of the education staff felt that it was their responsibility to carry out or carry out tasks related to administration and service.

With the responsibilities held by every employee can foster a sense of belonging to each employee. This condition increasingly provides a high level of awareness of the meaning of the success of each task or job that is a burden on employees in accordance with their respective job descriptions. In the minds of employees will be embedded that the success of the institution is also the success of employees. This will stimulate employee morale to always be successful in each of their activities which in the end the employee's performance is increasing. This is consistent with the opinion of Manz and Sims [18], that the existence of goals is focused on the attention and energy of employees where existence Organizational goals are aimed at improving organizational performance. 
So it can be concluded that the performance achieved by education staff is not influenced by the organizational climate but is influenced by other factors not examined including those that enable increased performance is the sense of responsibility possessed by the staff of the teaching staff themselves.

\subsection{Effect of Job Satisfaction on Performance}

Through the inferential statistical analysis using path analysis or multiple linear regression analysis, the third hypothesis which states job satisfaction has a significant effect on performance, is proven and the hypothesis is accepted.

From the picture above the direct effect of job satisfaction on performance is significant because the significance value of $t$ is smaller than 0.05 which is equal to 0,000 . The coefficient value of 0.405 means an increase in job satisfaction will be able to enhance the performance of educational staff by 0.405 . In addition to being influenced by job satisfaction, the performance of educational staff may also be influenced by other factors beyond this research. This means that job satisfaction is obtained because work is carried out in accordance with expertise, opportunities to attend education and training and promotion. This supports research from Samsi [19], which states that employees who feel job satisfaction and feel happy will be motivated to improve the quality and quantity of their work. The high level of employee job satisfaction significantly and positively influences their performance.

Path-Goal motivation theory, Vroom has shown that job satisfaction and performance are caused by completely different things. Job satisfaction is strongly influenced by the amount of reward that comes from work and the level of performance is strongly influenced by the basis of achievement of rewards. A person is satisfied with his work if his work gives them what they want and works effectively with the basis that effective performance can lead to the achievement of what is desired.

\section{CONCLUSIONS}

Organizational climate significantly influence job satisfaction. Organizational climate directly have no significant effect on performance. Job satisfaction significantly influence performance. To improve performance is better done by improving the organizational climate indirectly through the variable job satisfaction

Organizational climate must continue to be improved by paying more attention to job satisfaction so that later it will increase performance. Sriwijaya State Polytechnic needs to increase employee job satisfaction, this includes satisfaction with the payment of salary or wages, the work itself, co-workers leaders or superiors, job promotions and work environment. This is because employee job satisfaction has a significant and positive influence on the performance of Sriwijaya Polytechnic education staff. The Head of Sriwijaya State Polytechnic needs to provide the broadest opportunities or freedom to the staff of educational staff to increase motivation, ability, ideas and develop their own potential. With the opportunity or freedom that can create support and positive development of all activities carried out by employees in order to produce performance.

Sriwijaya State Polytechnic needs to conduct coaching programs in an integrated and intensive manner for educational staff, namely implementing education and training programs. With the coaching program, the skills and quality of technical knowledge, as well the work experience of the staff of the teaching staff is increasing, so as to be able to complete the tasks given well.

\section{REFERENCES}

[1] Setyawan, Donny, "Analisis Faktor-Faktor yang Mempengaruhi Kepuasan Kerja dan Relevansinya terhadap Komitmen Organisasi (Studi Kasus Pada Pemkab Temanggung). Tesis. Semarang: Universitas Diponegoro, 2005.

[2] Kristiana, Elia, "Pengaruh Iklim OrganisasiTerhadap Kinerja Karyawan PT. Top Harapan Motor”. Surabaya: Fakultas Ekonomi, Universitas Airlangga, 2011.

[3] Affandi, "Pengaruh Iklim Organisasi Terhadap Kepuasan Kerja, Komitmen dan Kinerja Karyawan (Studi Kasus Pada Pegawai di Lingkungan Kota Semarang)". Semarang: Program PascaSarjana Magister Manajemen, Universitas Diponegoro, 2002.

[4] Wirawan. "Budaya dan Iklim Organisasi Teori Aplikas idan Penelitian". Jakarta: Salemba Empat, 2007.

[5] Luthans, F, "Organizational Behavior", International Edition, McGraw Hill Book Co. Singapore, 1995.

[6] Anoraga, P and Widiyanti, N., Psychology in Companies. Jakarta: Rineka Cipta, 2004.

[7] Nia K., Effectof Organizational Climate on Employee Job Satisfaction at Bandung Geology Education and Training Center (Thesis FIP UPI, p 18), 2005.

[8] Sugiyono, "Metodologi Penelitian Administrasi", Alfabeta. Bandung, 2005. 
[9] Kreitner, Robert, dan Kinicki, Angelo., "Perilaku Organisasi”, Edisi Kelima, Salemba Empat. Jakarta, 2005.

[10] Hariandja, Marihot Effendi, "Manajemen Sumber Daya Manusia: Pengadaan, Pengembangan, Pengkompensasian, dan Peningkatan Produktivitas Pegawai. Jakarta: Grasindo, 2002.

[11] Panggabean, Mutiara S., "Manajemen Sumber Daya Manusia”, Cetakan Kedua. Jakarta: Ghalia Indonesia, 2004.

[12] Simamora, Henry, "Manajemen Sumber Daya Manusia”, Edisi ke-3, STIE YKPM. Yogyakarta, 2004.

[13] Robbins, Stephen P., "Perilaku Organisasi: Konsep, Kontroversi Aplikasi Jilid I dan II'. Edisi Indonesia, PT. Prenhallindo. Jakarta, 1996.

[14] Bangun, "Manajemen Sumber Daya Manusia", Jakarta: Erlangga, 2012.

[15] Deshpande, S.P. ,'The Impact of Ethical Climate type on facets of job satisfaction. Journal Of Business Ethics. 15. 655-660.,1997.

[16] Koh, H.C \& Boo \& Boo, E.H.Y., "The link Beetwen Organizational Ethics and Job Satisfaction": A Study Of Managers in Singapore. Journal Of Business Ethics 29:309-324, 2001.

[17] Wilson, Human Resource Management. PT. Erlangga. Bandung, 2012.

[18] Manz, CC. \& Sims Jr., "Superleadership: Leading Others To Lead Themselves", Prentice Hall Press, New York, 1990.

[19] Samsi, AM., "Pengaruh Komitmen Pimpinan, Komitmen Karyawan, Motivasi Kerja dan Kepuasan Kerja Karyawan Terhadap Kinerja Karyawan Pada PT. Persero Pelabuhan Indonesia III. Disertasi. Program Pascasarjana Universitas Brawijaya, Malang, 2006. 